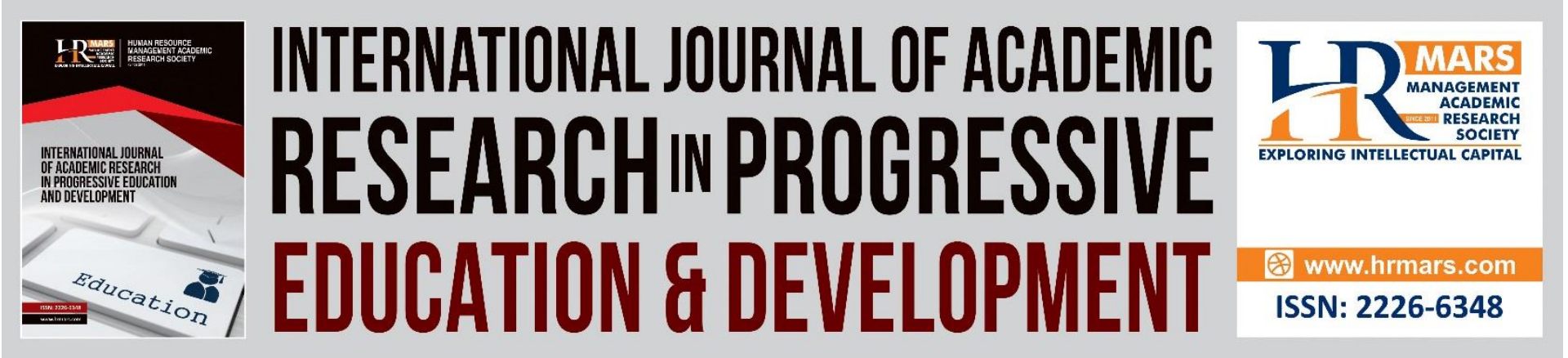

\title{
Analysing and Attending to Higher Secondary Students' Errors in Essay Writing
}

Janaki Manokaran, Porshothman Elenggoven

To Link this Article: http://dx.doi.org/10.6007/IJARPED/v10-i3/10827

DOI:10.6007/IJARPED/v10-i3/10827

Received: 07 June 2021, Revised: 10 July 2021, Accepted: 27 July 2021

Published Online: 18 August 2021

In-Text Citation: (Manokaran \& Elenggoven, 2021)

To Cite this Article: Manokaran, J., \& Elenggoven, P. (2021). Analysing and Attending to Higher Secondary Students' Errors in Essay Writing. International Journal of Academic Research in Progressive Education and Development, 10(3), 227-236.

Copyright: (C) 2021 The Author(s)

Published by Human Resource Management Academic Research Society (www.hrmars.com)

This article is published under the Creative Commons Attribution (CC BY 4.0) license. Anyone may reproduce, distribute, translate and create derivative works of this article (for both commercial and non-commercial purposes), subject to full attribution to the original publication and authors. The full terms of this license may be seen

at: http://creativecommons.org/licences/by/4.0/legalcode

Vol. 10(3) 2021, Pg. $227-236$

Full Terms \& Conditions of access and use can be found at http://hrmars.com/index.php/pages/detail/publication-ethics 


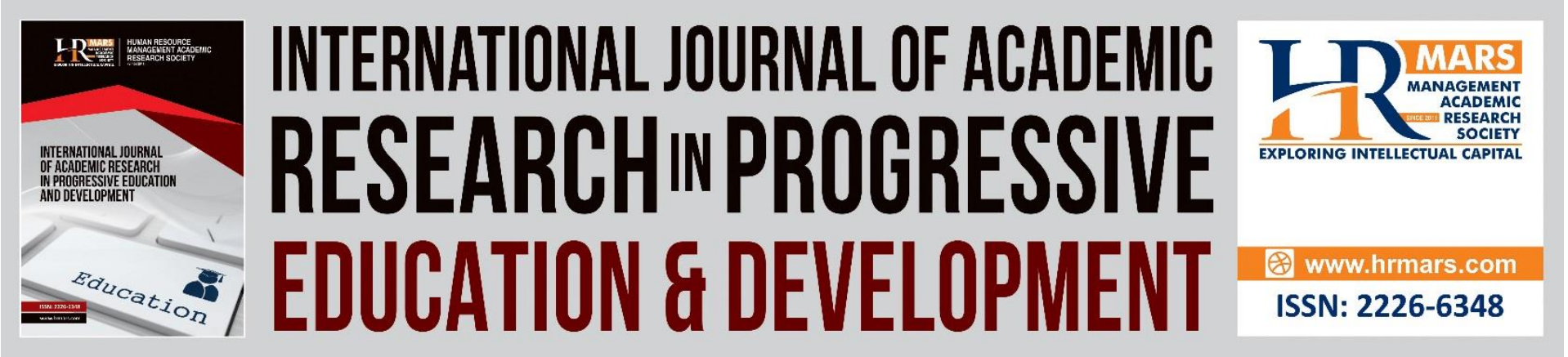

\title{
Analysing and Attending to Higher Secondary Students' Errors in Essay Writing
}

\author{
Janaki Manokaran ${ }^{1}$, Porshothman Elenggoven² \\ ${ }^{1}$ Centre of Foundation Studies, Universiti Teknologi MARA, Cawangan Selangor, Kampus \\ Dengkil 43800 Dengkil, Selangor, Malaysia, ${ }^{2}$ Sekolah Menengah Jenis Kebangsaan Chung \\ Hua, 72000, Kuala Pilah, Negeri Sembilan. \\ Email: janakimanokaran88@gmail.com
}

\begin{abstract}
Learning a Second Language (L2) is a lifelong process and it is often a challenging experience for L2 learners. Malaysian ESL students are still weak in English, especially in their writing skills. They still seem to commit errors in all aspects of language. With that in line, this study aimed to identify the problems frequently faced by ESL students in essay writing, create an intervention plan to improve their writing skills and suggest some possible ways to overcome the writing problems faced by Malaysian ESL students. This study employed pre- and post tests methods in collecting the data. Subject Verb Agreement, Past Tense, Lack of Vocabulary and Sentence Structure were the identified errors. Intervention was planned and conducted for 6 weeks. Students post-test scores showed a great improvement in their writing. By identifying the common errors made by the students, the teachers can be well versed to assist the students to minimalize and overcome their language problems in writing. Therefore, all teachers are suggested to deeply give attention to their students' errors and practice innovative methods to face these complexities' in writing classes.
\end{abstract}

Keywords: Error Analysis, Secondary Students, Writing, Intervention

\section{Introduction}

Learning a Second Language (L2) is a lifelong process and it is often a challenging experience for L2 learners. English has become the L2 after it was introduced to Malaysia during colonization. In general, Malaysian students have been exposed to eleven years of learning English in primary and secondary schools.

English has the status of a L2 in the Malaysian education system in both primary and secondary schools. However, learning English as a L2 is not an easy task. In order to master the English language, learners have to be adequately exposed to all of the four basic skills, namely listening, speaking, reading and writing (Brown, 2000). Language teaching in Malaysia is currently focusing on the teaching and learning of these four language skills. However, the standard of English among Malaysian students in schools is on the decline despite learning English for several years (Darus \& Subramaniam, 2009). Malaysian students are still weak in 
DEVELOPMENT

Vol. 10, No. 3, 2021, E-ISSN: 2226-6348 @ 2021 HRMARS

English, especially in their writing skills. They still seem to commit errors in all aspects of language.

The written works of Malaysian ESL learners have shown that their writings are full of errors. Of the four English skills, writing has been found to be the most difficult for L2 learners to master, especially in Malaysian secondary schools where English is mainly taught as a compulsory subject.

Individuals with writing problems may have difficulties in one or more aspects of writing skill such as proper use of grammar, punctuation, capitalization, spelling, and some of the basic and initiating aspects of writing. It is also an unpleasant piece of work for both teachers and L2 learners in ESL classes. This subject of study is provoked not only because of the researchers' interests as a teacher in the second language field, but also due to interest as researcher who is engaged in ESL class in order to identify the cause of these problems faced by the $L 2$ learners in ESL classes.

Errors in writing such as tenses, prepositions and weak vocabulary are the most common and frequent type of errors that are committed by $L 2$ learners. The learners usually face difficulties in learning the grammatical aspects of the English Language, such as in subject-verb agreement, the use of connectors, articles and the use of correct sentence structure. Thus, restoration of interest in the area of learner errors can be considered as a wisely move. Teachers who can analyze and treat errors effectively are better equipped to help their students become more aware of their errors.

The use of Error Analysis and Data Driven techniques can aid to an effective teaching and learning of English. Mistakes are expected in all stages of teaching and learning, but teachers who can analyse and treat the errors with good interventions are well prepared in helping their students to be aware of the mistakes that they made. This shows that, errors are a tool to aid us and it should be viewed positively.

\section{Objective}

This leads to the objective of the study, which is to investigate the types of errors made by Form Four students in Kuala Pilah in their written work. This study had three main objectives. First, it aimed to identify the problems frequently faced by ESL students in essay writing. Second, it intended to create an intervention plan to improve their writing skills and third, to suggest some possible ways to overcome the writing problems faced by Malaysian ESL students.

This is an approach in helping teachers design pedagogical interventions that foster cycles of student improvement. This initiative helps students to prepare for the Sijil Pelajaran Malaysia (SPM) Examination and to develop reflective practitioners committed to fostering cycles of student improvement through responsive, student-centered pedagogy. This will help the teachers to adopt this approach and infuse it in their lessons.

\section{Motivation and Contribution of the Study}

This paper is significant in its subject matter of this study. The findings of this study provide the knowledge about different types of errors committed by the students and at the same 
DEVELOPMENT

Vol. 10, No. 3, 2021, E-ISSN: 2226-6348 @ 2021 HRMARS

time the guidance in addressing those errors. This study also attached some effective Lesson Plans for Upper Secondary teachers as a reference in order to tackle the errors committed by the learners.

\section{Theoretical Framework}

The Error Analysis (EA) approach was used in this study. The field of Error Analysis studies were prominence in the 1970s by S.P Corder. Error Analysis has five different steps in the process namely Collection of the sample, Identification of errors, Description of Errors, Explanation of errors and Evaluation of errors.

\section{Research Method}

\section{Context of the Study}

The location of the study was a secondary school, SMJK Chung Hua which is in the heart of Kuala Pilah town. This school is approximately 35 kilometers away from Seremban. The school runs in single teaching session. There were 497 students and 49 teachers in this school. Kuala Pilah is a sub-urban with small number of population. It has a sizeable Chinese community that has existed since the early British rule. This community today engages in trading and providing essential services such as workshops, coffee shops and saloons. There are limited numbers of entertainment outlets for the community to visit. Coffee shops and internet cafes that sprouted in 1990's are the main source of entertainment for the locals.

\section{Participants}

A number of 15 Form Four students participated in this study. All of them had their primary education in Chinese Vernacular schools, in which Chinese was the medium of instruction. English was taught as an additional subject in line with the Education Ministry policy to foster English language in this country. The respondents are from Form 4 Harmoni class comprising of 7 boys and 8 girls. All of the participants have experienced approximately the same number of 10 years of the education through the primary and secondary education system. All of the respondents speak Mandarin at home except for one student who speaks English at home.

\section{Procedure}

\section{A. Pre-Test}

The student participants of this study were selected from a secondary school in Kuala Pilah, Negeri Sembilan. First, the consent of the Principal of the secondary school was obtained for the research to take place in the school. The teacher arranged a meeting between the teacher and student participants after schooling period. During the meeting, a thorough explanation was provided on the journey of this study. The objectives of the study were also explained to the student participants to give a wider perspective to them about the study.

The teacher selected 4 Harmoni students because the teacher is teaching that particular class and it is easier to conduct the study without any other physical interference. Examination sheets were given to the students in classroom to write the essays immediately. They were required to write an essay entitled "The Person I Admire". They were given estimated one hour to complete their essays. The essays were immediately collected. Then, the essays were examined by the teacher. Teacher focused on the stages of writing process: brainstorming, outlining, development of paragraphs, editing and grammatical errors, while examining the essays. 
INTERNATIONAL JOURNAL OF ACADEMIC RESEARCH IN PROGRESSIVE EDUCATION AND DEVELOPMENT

Vol. 10, No. 3, 2021, E-ISSN: 2226-6348 @ 2021 HRMARS

Data provides evidence to help teachers to identify the gaps in students understanding of the language. The teacher tabulated the errors made by the students according to the number of student participant and the specific errors made by the students. From the table, the teacher identified the most common types of gaps revealed by the student participants' data. To unpack the gaps emerged commonly among the students, the teacher prioritized four major types of gaps that were revealed through the table. The four major types of gaps that were identified to be unpacked were listed in the table below:

\begin{tabular}{|c|c|c|c|c|c|c|}
\hline & & & & & む & \\
\hline & $\begin{array}{l}\stackrel{n}{5} \\
\stackrel{u}{g} \\
\frac{5}{n}\end{array}$ & 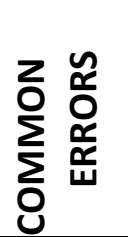 & $\stackrel{\mathbb{3}}{3}$ & 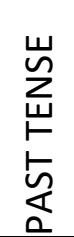 & 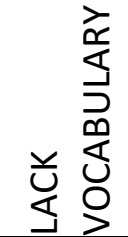 & 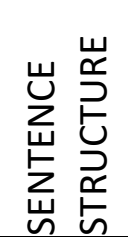 \\
\hline SS1 & & & 1 & I & I & 1 \\
\hline SS2 & & & / & / & I & I \\
\hline SS3 & & & I & & & \\
\hline SS4 & & & & / & / & I \\
\hline SS5 & & & & I & I & \\
\hline SS6 & & & & / & / & \\
\hline SS7 & & & I & I & I & I \\
\hline SS8 & & & / & / & 1 & / \\
\hline SS9 & & & I & I & I & I \\
\hline SS10 & & & / & / & I & / \\
\hline SS11 & & & & I & I & I \\
\hline SS12 & & & / & / & I & / \\
\hline SS13 & & & I & I & I & I \\
\hline SS14 & & & / & / & / & \\
\hline SS15 & & & I & I & I & I \\
\hline TOTAL & & & 11 & 14 & 14 & 11 \\
\hline$\%$ & & & 73 & 93 & 93 & 73 \\
\hline
\end{tabular}

Table 1: The Pre-Test result

Next, the teacher transferred the data into a graph form. Graph 1 shows the analysis of errors based on the types of errors, number of errors and percentage of errors committed by the student participants. 


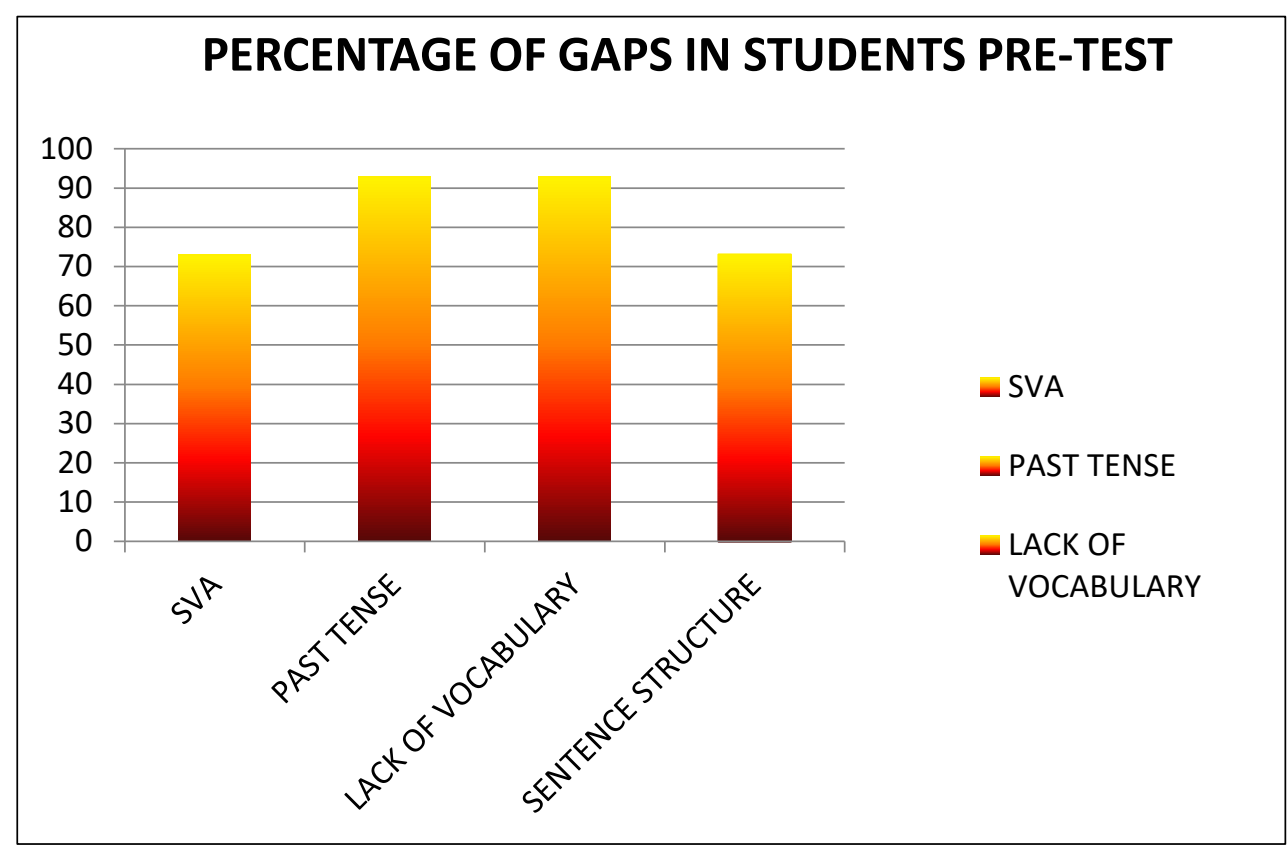

Graph 1: The Percentage of Gaps in Students Pre-Test

\section{B. Intervention Plan}

The students with language impairments often have difficulties in many areas of language, but grammar is particularly affected. Thus, there is a need to establish the best ways to help the students with language impairments to improve their proficiency. So, the best approach to achieve this by developing an intervention plan. The ultimate goal of intervention plan is to establish which method or activity is the most effective way to rectify the types of gaps identified from the pre-test.

In order to solve these impairments, teacher created a six weeks intervention plans based on the four types of gaps revealed through the pre-test data. The interventions were designed to treat gaps ranked first four in the prioritized list. Teacher designed awareness activity before introducing a new type of gap to raise awareness of gaps in the student participants' knowledge and skills through whole-class feedback. Teacher incorporated student data in his intervention strategies to make the exercises more relevant and authentic for the student participants. The errors used were the authentic sentences or passages extracted from students' previous works. Teacher prepared a series of lesson for each type of gap. The lessons created were to unpack the gaps and as part of helping student participants to prepare for the post-test.

The activities were conducted based on the intervention plan provided below: 


\begin{tabular}{|c|c|c|c|c|}
\hline WEEK & $\begin{array}{l}\text { GAP IN } \\
\text { KNOWLEDGE } \\
\text { AND SKILL }\end{array}$ & $\begin{array}{l}\text { CURRICULUM } \\
\text { LPECIFICATIONS. } \\
\text { LEARNING OBJECTIVE AND } \\
\text { SUCCESS CRITERIA }\end{array}$ & ACTIVITIES & RESOURCES \\
\hline 1 & Past Tense & 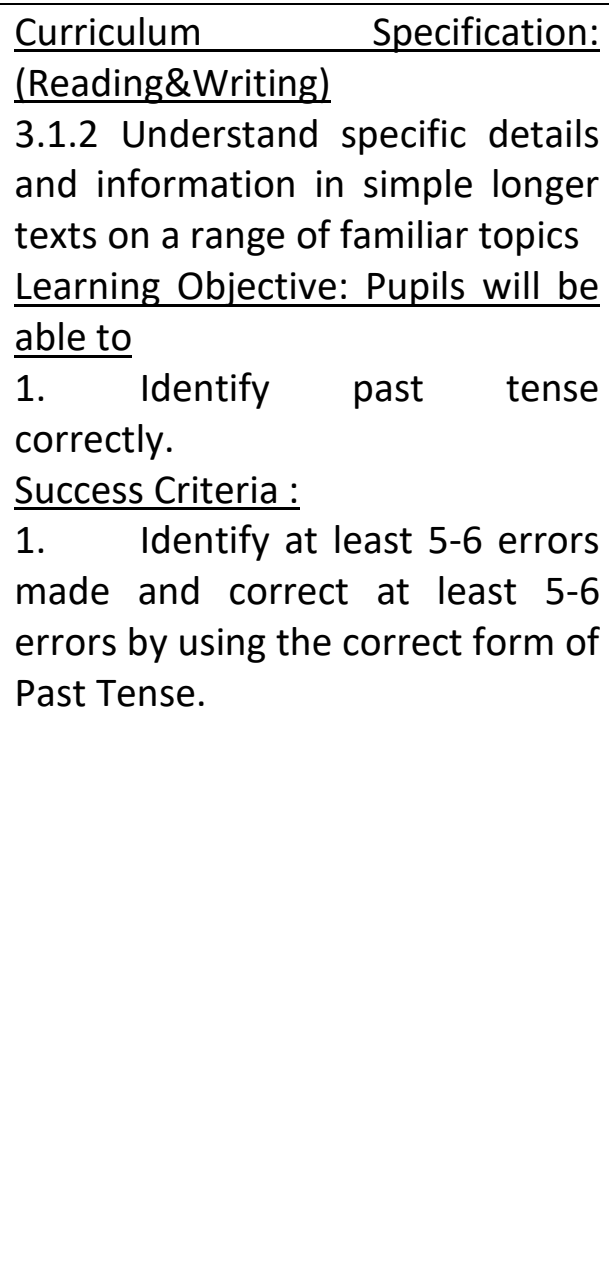 & $\begin{array}{l}\text { CREATING AWARENESS } \\
\text { ACTIVITY } \\
\text { ACTIVITY: STICKY NOTES } \\
\text { (30mins) } \\
\text { 1. On the walls of the class, } \\
\text { teacher put up some sentences } \\
\text { containing errors from pupils' } \\
\text { essays. } \\
\text { 2. Teacher asks pupils to work } \\
\text { in pairs and give each pair a } \\
\text { number and as many sticky } \\
\text { notes. } \\
\text { 3. Teacher asks students to } \\
\text { walk around the classroom, } \\
\text { read the sentences containing } \\
\text { the errors, and discuss how to } \\
\text { correct them. Teacher asks } \\
\text { students to write the correct } \\
\text { version on the sticky note } \\
\text { together with their number, } \\
\text { and stick it next to the } \\
\text { sentence. (Gallery Walk) } \\
\text { 4. Teacher takes sentence } \\
\text { number one and asks the class } \\
\text { as a whole to discuss the error. }\end{array}$ & $\begin{array}{l}\text { Student's } \\
\text { work } \\
\text { - Sticky } \\
\text { notes } \\
\text {-Students } \\
\text { Essay. }\end{array}$ \\
\hline 1 & Past Tense & $\begin{array}{l}\text { Curriculum Specification (writing) } \\
1.1 .2 \text { Presenting information in } \\
\text { non-linear forms including tables, } \\
\text { graphs, diagrams, charts. } \\
\text { Learning Objective: Pupils will be } \\
\text { able to } \\
1 . \quad \text { Complete the timeline } \\
\text { based on the questions and other } \\
\text { events. } \\
2 . \quad \text { Write a short paragraph } \\
\text { using the timeline. } \\
\text { Success Criteria: } \\
1 . \quad \text { Complete the timeline by } \\
\text { using at least 5-6 questions given. } \\
2 . \quad \text { Create a timeline based on } \\
\text { other events. }\end{array}$ & $\begin{array}{l}\text { INTERVENTION PLAN } \\
\text { 1.Pupils are divided into group } \\
\text { according to their level. } \\
\text { 2.Teacher asks pupils to } \\
\text { complete a timeline based on } \\
\text { the questions. } \\
\text { 3. using the same information, } \\
\text { teacher asks pupils to write the } \\
\text { date on the bottom and the } \\
\text { event on top of the timeline. } \\
\text { 4. Teacher asks pupils to think } \\
\text { of other event for example } \\
\text { their years in school, and chart } \\
\text { it on a timeline. } \\
\text { 5. Pupils create 4-5 simple } \\
\text { sentences using the timeline. } \\
\text { 6. Classroom discussion. }\end{array}$ & $\begin{array}{l}\text { Worksheet } \\
1 \\
\text { (Make a } \\
\text { Timeline) }\end{array}$ \\
\hline
\end{tabular}




\begin{tabular}{|c|c|c|c|c|}
\hline & & $\begin{array}{l}\text { 3. Write } 4-5 \text { sentences based } \\
\text { on the timeline. }\end{array}$ & & \\
\hline 2 & Past Tense & 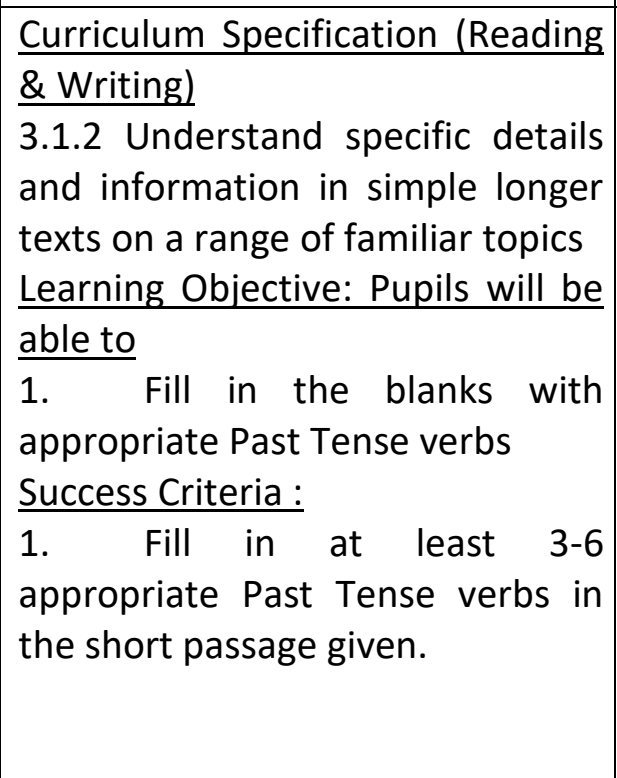 & $\begin{array}{l}\text { INTERVENTION PLAN } \\
\text { 1.Individual Work- Each pupil is } \\
\text { given a short passage on Past } \\
\text { Tense. } \\
\text { 2. Pupils are required to fill in } \\
\text { the blanks by using appropriate } \\
\text { Past Tense verbs } \\
\text { 3. Peer Marking- Teacher } \\
\text { selects a few pupils to give out } \\
\text { their answers (correct them if } \\
\text { necessary) and pupils mark } \\
\text { their friend's answers. } \\
\text { 4. Pupils take back their } \\
\text { worksheet and teacher discuss } \\
\text { with the whole class. }\end{array}$ & $\begin{array}{l}\text { Worksheet } \\
2\end{array}$ \\
\hline 2. & $\begin{array}{l}\text { Subject Verb } \\
\text { Agreement }\end{array}$ & $\begin{array}{l}\text { Curriculum Specification (Reading) } \\
3.1 .2 \text { Understand specific details } \\
\text { and information in simple longer } \\
\text { texts on a range of familiar topics } \\
\text { Learning Objective: Pupils will be } \\
\frac{\text { able to }}{1 . \quad \text { Rearrange and identify the }} \\
\text { correct pattern of sentences. } \\
\text { Success Criteria : } \\
\begin{array}{l}1 . \quad \text { Rearrange at least } 1-3 \\
\text { jumble up words to form a correct } \\
\text { pattern of sentence }\end{array}\end{array}$ & 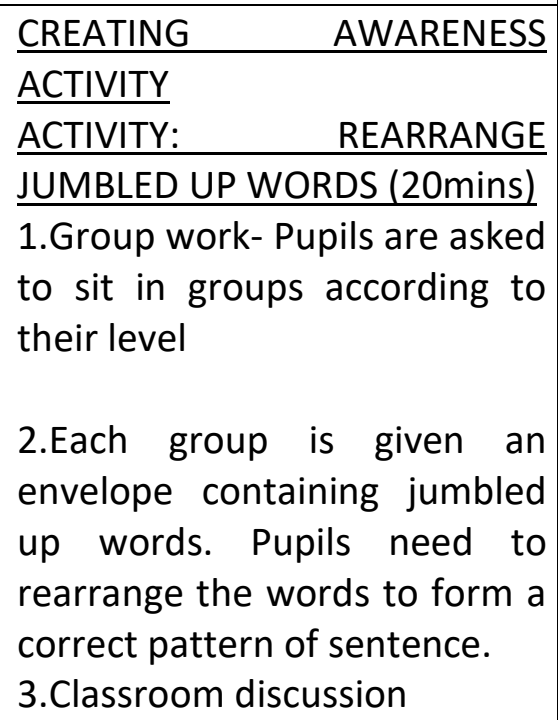 & \\
\hline
\end{tabular}




\begin{tabular}{|c|c|c|c|c|}
\hline 3. & $\begin{array}{l}\text { Subject Verb } \\
\text { Agreement }\end{array}$ & 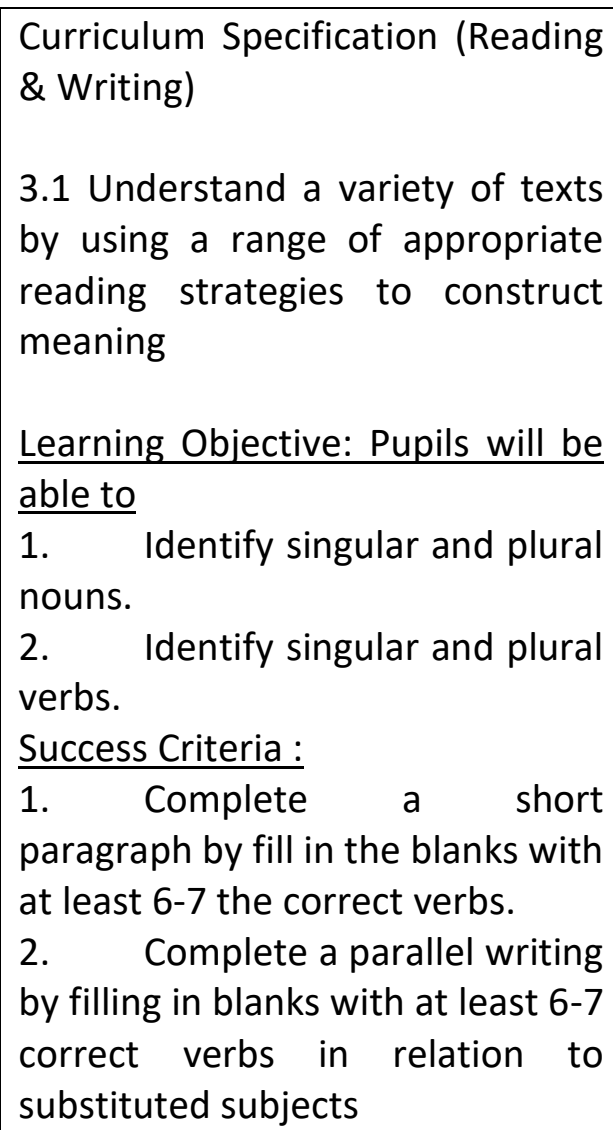 & $\begin{array}{l}\text { INTERVENTION PLAN } \\
\text { (PARALLL WRITING) } \\
\text { 1. Pupils are given } \\
\text { worksheet 3. } \\
2 . \quad \text { Teacher asks students } \\
\text { to complete the worksheet by } \\
\text { fill in the blanks with correct } \\
\text { verbs. Pupils should copy the } \\
3 . \quad \text { piece of } \\
\text { paragraph on a paper and make } \\
\text { notebook pers. } \\
\text { correction among their peers. } \\
4 . \quad \text { Teacher distributes } \\
\text { worksheet } 4 . \\
5 . \quad \text { Teacher substitutes the } \\
\text { subjects in worksheet } 2 . \\
6 . \quad \text { Teacher asks pupils to } \\
\text { fill in the blanks with correct } \\
\text { verbs in relations to the } \\
\text { substituted subjects. } \\
7 . \quad \text { Classroom discussion. }\end{array}$ & $\begin{array}{l}\text { Worksheet } \\
3 \\
\text { Worksheet } \\
4\end{array}$ \\
\hline 3. & $\begin{array}{l}\text { Subject Verb } \\
\text { Agreement }\end{array}$ & 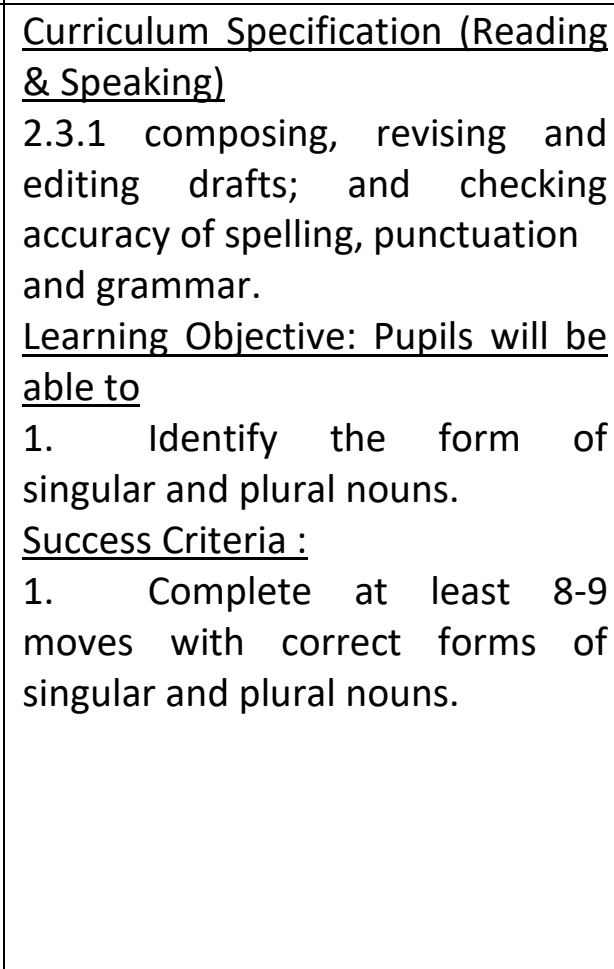 & $\begin{array}{l}\text { INTERVENTION (RACE TO THE } \\
\text { FINISH) } \\
1 . \quad \text { Pupils sit in pairs. } \\
2 . \quad \text { Pupils are given } \\
\text { worksheet } 5 . \\
3 . \quad \text { Teacher explains the } \\
\text { rules of the game: } \\
\text { Move } 1 \text { space for correct } \\
\text { singular nouns. } \\
\text { Move } 2 \text { spaces for correct } \\
\text { plural nouns. } \\
4 . \quad \text { Pupils fill the blanks } \\
\text { with correct singular and plural } \\
\text { nouns on their turn. } \\
5 . \quad \text { The player wholands on } \\
\text { finish is the winner. } \\
6 . \quad \text { Pupils then orally share } \\
\text { the answers with the whole } \\
\text { class. }\end{array}$ & $\begin{array}{l}\text { Worksheet } \\
5\end{array}$ \\
\hline
\end{tabular}




\begin{tabular}{|c|c|c|c|c|}
\hline 4. & $\begin{array}{l}\text { Sentence } \\
\text { Structure }\end{array}$ & $\begin{array}{l}\text { Curriculum Specification (Reading } \\
\text { \& Speaking) } \\
2.3 .1 \text { composing, revising and } \\
\text { editing drafts; and checking } \\
\text { accuracy of spelling, punctuation } \\
\text { and grammar. } \\
\frac{\text { Learning Objective: Pupils will be }}{\text { able to }} \\
1 . \quad \text { Identify form of sentence } \\
\text { structure correctly. } \\
\text { Success Criteria : } \\
1 . \quad \text { Identify at least 5-6 errors } \\
\text { made and correct at least 5-6 } \\
\text { errors by using the correct form of } \\
\text { sentence structure. }\end{array}$ & 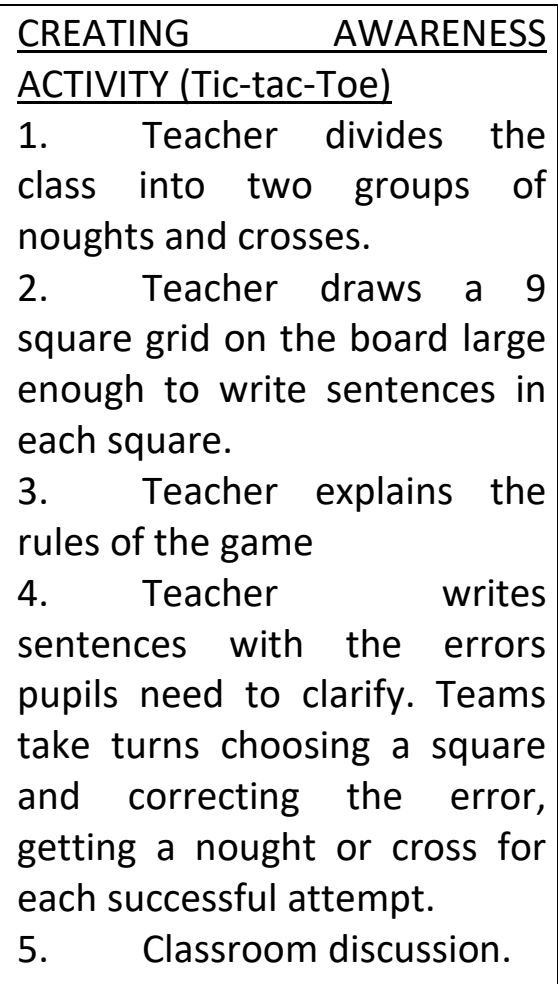 & \\
\hline 4. & $\begin{array}{l}\text { Sentence } \\
\text { Structure }\end{array}$ & 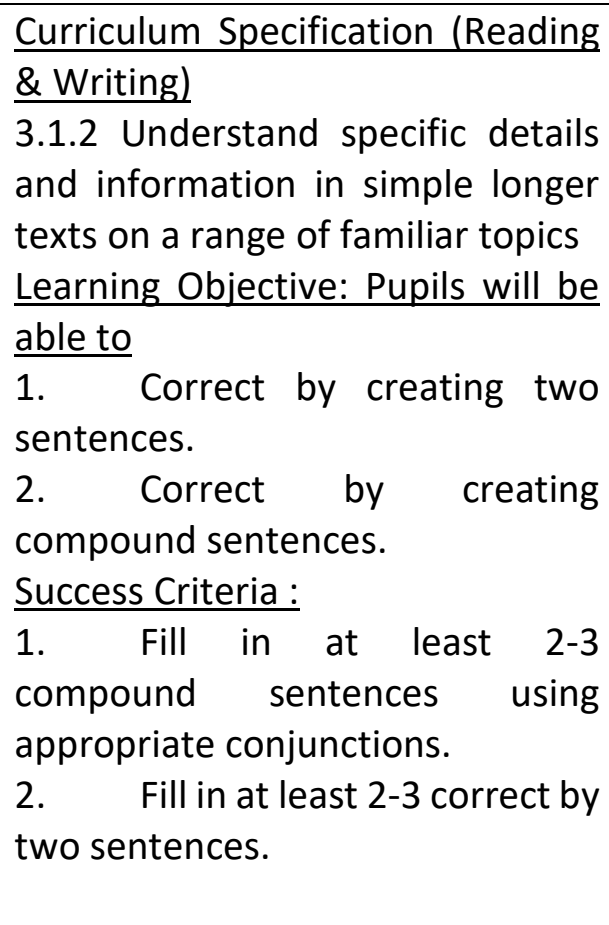 & $\begin{array}{l}\text { INTERVENTION (RUN-ON } \\
\text { SENTENCES) } \\
\text { 1.Individual Work- Each pupil is } \\
\text { given worksheet } 6 \text { on run on } \\
\text { sentences. } \\
\text { 2. Pupils are required to fill in } \\
\text { the blanks by using appropriate } \\
\text { conjunctions, creating two } \\
\text { correct sentences and } \\
\text { compound sentences. } \\
\text { 3. Peer Marking- Teacher } \\
\text { selects a few pupils to give out } \\
\text { their answers (correct them if } \\
\text { necessary) and pupils mark } \\
\text { their friend's answers. } \\
\text { 4. Pupils take back their } \\
\text { worksheet and teacher discuss } \\
\text { with the whole class. }\end{array}$ & $\begin{array}{l}\text { Worksheet } \\
6\end{array}$ \\
\hline 5. & $\begin{array}{l}\text { Sentence } \\
\text { Structure }\end{array}$ & $\begin{array}{l}\text { Curriculum Specification (Reading } \\
\text { \& writing) } \\
2.3 .1 \text { composing, revising and } \\
\text { editing drafts; and checking } \\
\text { accuracy of spelling, punctuation } \\
\text { and grammar. }\end{array}$ & $\begin{array}{l}\text { INTERVENTION } \\
\text { SENTENCES) } \\
1 . \quad \text { Pupils are given } \\
\text { worksheet 7. } \\
2 . \quad \text { Teacher asks students } \\
\text { to complete the worksheet, } \\
\text { identifying the correct }\end{array}$ & $\begin{array}{l}\text { Worksheet } \\
7 \\
\text { Worksheet } \\
8\end{array}$ \\
\hline
\end{tabular}




\begin{tabular}{|c|c|c|c|c|}
\hline & & $\begin{array}{l}\text { Learning Objective: Pupils will be } \\
\frac{\text { able to }}{1 . \quad \text { Identify the form of }} \\
\text { sentence structure correctly. } \\
\text { Success Criteria : } \\
1 . \quad \text { Complete at least } 8-9 \text { run } \\
\text { on sentences with correct forms of } \\
\text { sentence structure. }\end{array}$ & $\begin{array}{l}\text { sentences by putting a check } \\
\text { beside each sentence. } \\
3 . \quad \text { Pupils should rewrite } \\
\text { the run on sentences as two } \\
\text { sentences in the lines provided. } \\
4 . \quad \text { Teacher distributes } \\
\text { worksheet } 8 \text {. } \\
5 . \quad \text { Teacher asks pupils to } \\
\text { fix the run on sentences. } \\
6 . \quad \text { Classroom discussion. }\end{array}$ & \\
\hline 5. & $\begin{array}{l}\text { Sentence } \\
\text { Structure }\end{array}$ & 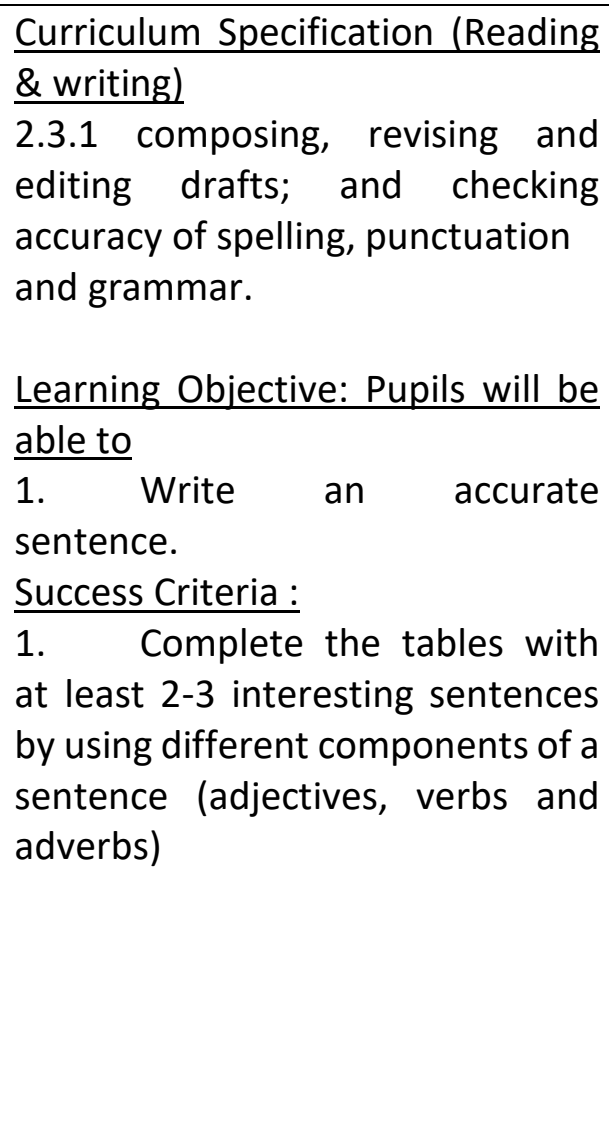 & $\begin{array}{l}\text { INTERVENTION (DRESSING UP } \\
\text { A SENTENCE) } \\
\text { 1. Pupils sit in their } \\
\text { respective groups. } \\
2 . \quad \text { Teacher provides each } \\
\text { group with a laminated } \\
\text { "Dressing up sentence" } \\
\text { template. } \\
3 . \quad \text { Teacher asks pupils to } \\
\text { take simple, boring sentences } \\
\text { from the box. } \\
4 . \quad \text { Teacher instructs pupils } \\
\text { to write the boring sentences } \\
\text { on top of the template. } \\
5 . \quad \text { Pupils required filling up } \\
\text { the template which will guide } \\
\text { them in how to add the } \\
\text { sentence. } \\
6 . \quad \text { Teacher asks pupils to } \\
\text { share their interesting } \\
\text { sentences. } \\
7 . \quad \text { Classroom discussion. }\end{array}$ & $\begin{array}{l}\text { Worksheet } \\
9\end{array}$ \\
\hline 5. & Vocabulary & $\begin{array}{l}\text { Curriculum Specification } \\
\text { (Speaking) } \\
4.2 \quad \text { Communicate with } \\
\text { appropriate language, form and } \\
\text { style } \\
4.2 .4 \text { : Use register appropriately } \\
\text { (according to the topic) } \\
\frac{\text { Learning objective: Pupils will be }}{\text { able to }} \\
\begin{array}{l}\text { adjectives correctly. }\end{array}\end{array}$ & $\begin{array}{l}\text { CREATING AWARENESS } \\
\text { ACTIVITY } \\
\text { 1. Pupils are given a } \\
\text { sample of their essay. Some of } \\
\text { the words which are } \\
\text { inappropriately used in the } \\
\text { sentences are highlighted } \\
2 . \quad \text { Pupils are given a new } \\
\text { set of adjectives to replace the } \\
\text { words highlighted }\end{array}$ & \\
\hline
\end{tabular}




\begin{tabular}{|c|c|c|c|c|}
\hline & & $\begin{array}{l}\text { Success Criteria : } \\
1 . \quad \text { Replace at least 3-5 words } \\
\text { from the essay sample with } \\
\text { adjectives given }\end{array}$ & $\begin{array}{l}\text { 3. Pupils replace the } \\
\text { highlighted words with a new } \\
\text { set of adjectives } \\
\text { 4. Pupils then orally share } \\
\text { with the whole class. }\end{array}$ & \\
\hline 6. & Vocabulary & 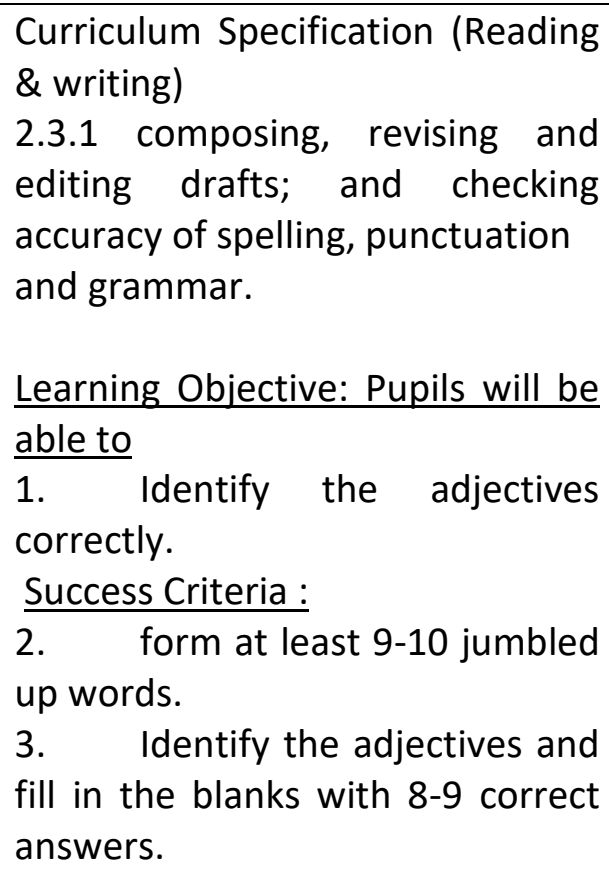 & 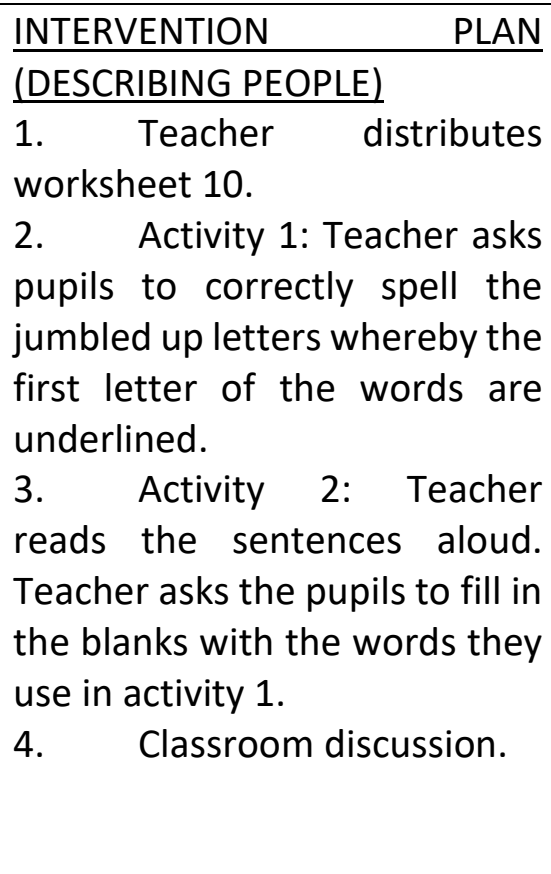 & $\begin{array}{l}\text { Worksheet } \\
10\end{array}$ \\
\hline 6. & Vocabulary & $\begin{array}{l}\text { Curriculum Specification (Listening } \\
\text { \& Writing) } \\
1.1 \text { Obtain information for } \\
\text { different purposes by } \\
1.1 .1 \text { listening to spoken texts } \\
\text { such as talks, speeches and } \\
\text { viewing television, documentaries } \\
\text { and multimedia; } \\
1.1 .2 \text { interviewing and using } \\
\text { questionnaires } \\
\text { Learning Objectives: Pupils will be } \\
\text { able to } \\
1 . \quad \text { Identify } \\
\text { adjectives that suit the character } \\
\text { traits. } \\
2 . \quad \text { Write a short paragraph } \\
\text { using the adjective and character } \\
\text { traits given. }\end{array}$ & 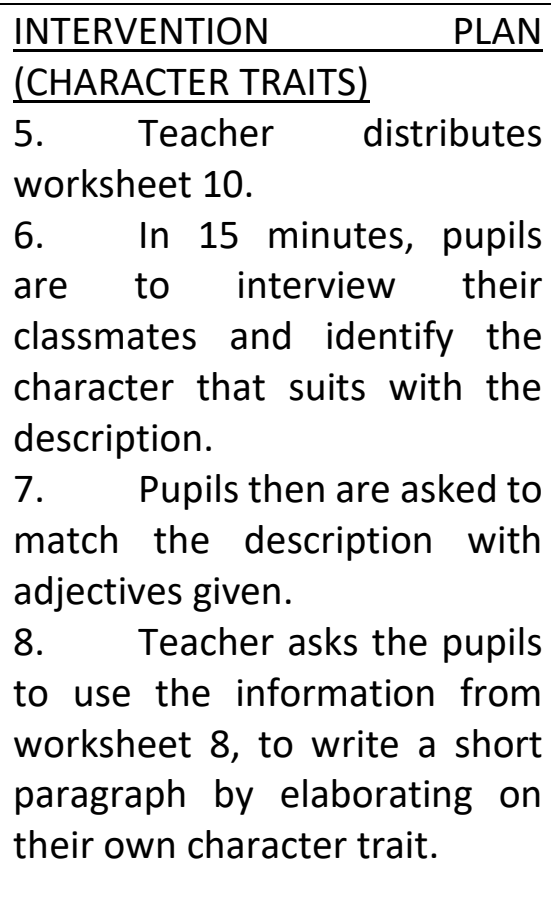 & $\begin{array}{l}\text { Worksheet } \\
11\end{array}$ \\
\hline
\end{tabular}




\begin{tabular}{|l|l|l|}
\hline & $\begin{array}{l}\text { Success Criteria: } \\
1 . \quad \text { Gather information and } \\
\text { acquire knowledge to write a } \\
\text { descriptive essay by interviewing } \\
\text { their classmates. } \\
2 . \quad \text { Identify at least 6-7 } \\
\text { adjectives that suit the character } \\
\text { traits appropriately. } \\
\text { 3. Write at least one short } \\
\text { paragraph by using as many words } \\
\text { listed previously as possible. }\end{array}$ \\
\hline 7 & Post - test & MY IDEAL BOYFRIEND / GIRLFIEND \\
\hline
\end{tabular}

While completing all the activities in this intervention plan, the teacher informally assesses the student participants. At the end of each type of gap, teacher asked the student participants to write a short excerpt based on the gap that they learnt. Teacher examined the excerpts to identify the level of improvements showed or produced by the students. These short writing tasks were given to the students as an individual work. The errors and the length of the excerpts help the teacher to measure the improvement in the students' grammar impairments.

The intervention plan prepared by the teacher was too ambitious in relation to the students' performance. Teacher made slight changes with the worksheet prepared earlier. The student participants were mixed-ability students. To cater all type of students, the difficulty level of the worksheets was lowered. This is to suit the weaker students in the class. In addition, group works were assigned while the students' participants involved in the activities. By conducting group activity, the advanced students will able to assist the moderate and weaker student participants. This is to assist the students with low self-esteem as they are weak in English.

\section{Post-Test and Outcomes of the Intervention}

After six weeks of intervention plan, a post-test was carried out on the seventh week. Teacher allocated one hour for the student participants to sit for the test. The allocated time was as the same as pre-test. Extra minutes were given to the student participants who unable to complete it within the time limit. The post-test was conducted in 4 Harmoni.

The question for the pot-test was similar to the pre-test, where student participants need to write a descriptive essay about a person. The tittle given for the post-test was "My Ideal Boyfriend / Girlfriend". This type of question was questioned in SPM examination section B: Continuous Writing. Student participants were required to write a 350 words essay.

After the examining of the post-test, the obtain results showed that the student participants did well in post-test compared to the pre-test. Even though the errors committed by the student participants shows some rapid improvement, but certain students are still making the same errors in their writing. The result of the pot-test is shown below: 


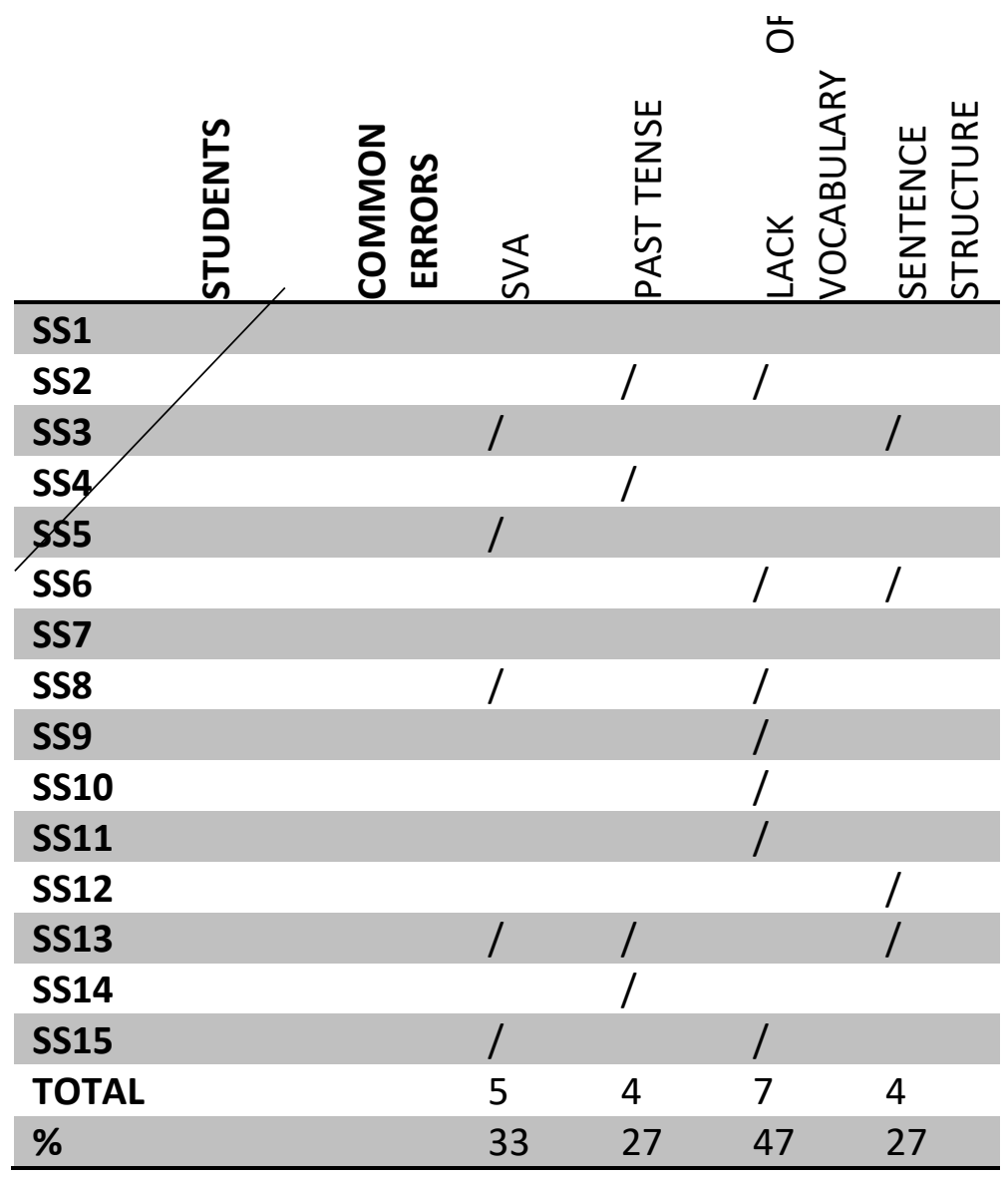

Table 2: The Post-Test Result

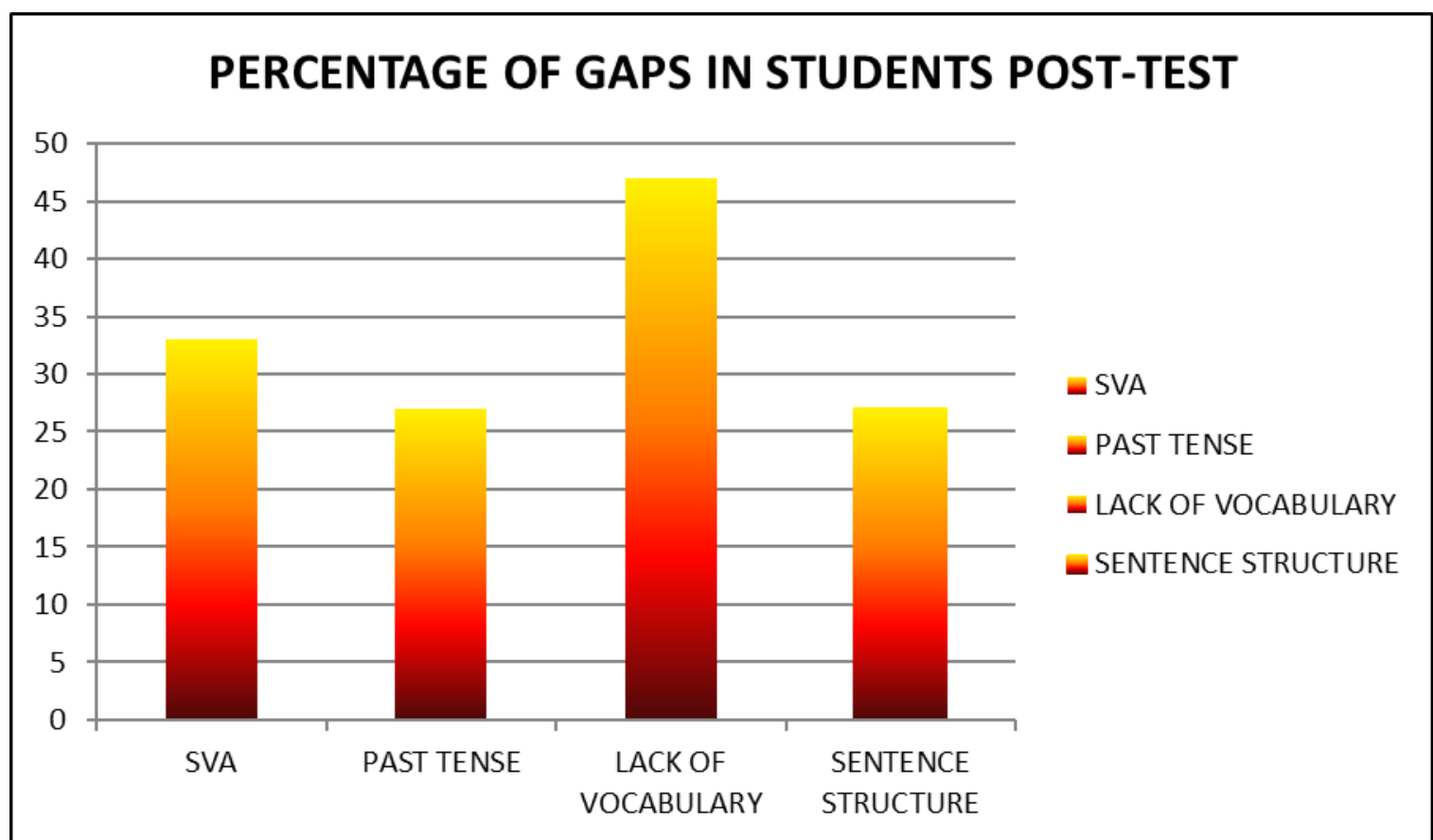

Graph 2: The Percentage of Gaps in Students Post-Test

As can be seen in Table 2 above, Student 1 (SS1) and Student 7(SS7) showed a drastic improvement in their writing. They able to unpack the four type of gaps identified which are 
DEVELOPMENT

Vol. 10, No. 3, 2021, E-ISSN: 2226-6348 @ 2021 HRMARS

the most common errors committed by the student participants in the pre-test. This significant result in students writing probably shows that the intervention plan guided the students to write a good piece of writing.

\section{Improvement from the Students}

After six weeks of intervention, the student participants showed a great improvement in their writing. This is evident after the student participants engaged in this intervention plan from week one till week six. The graph below will help use to see the improvements clearly.

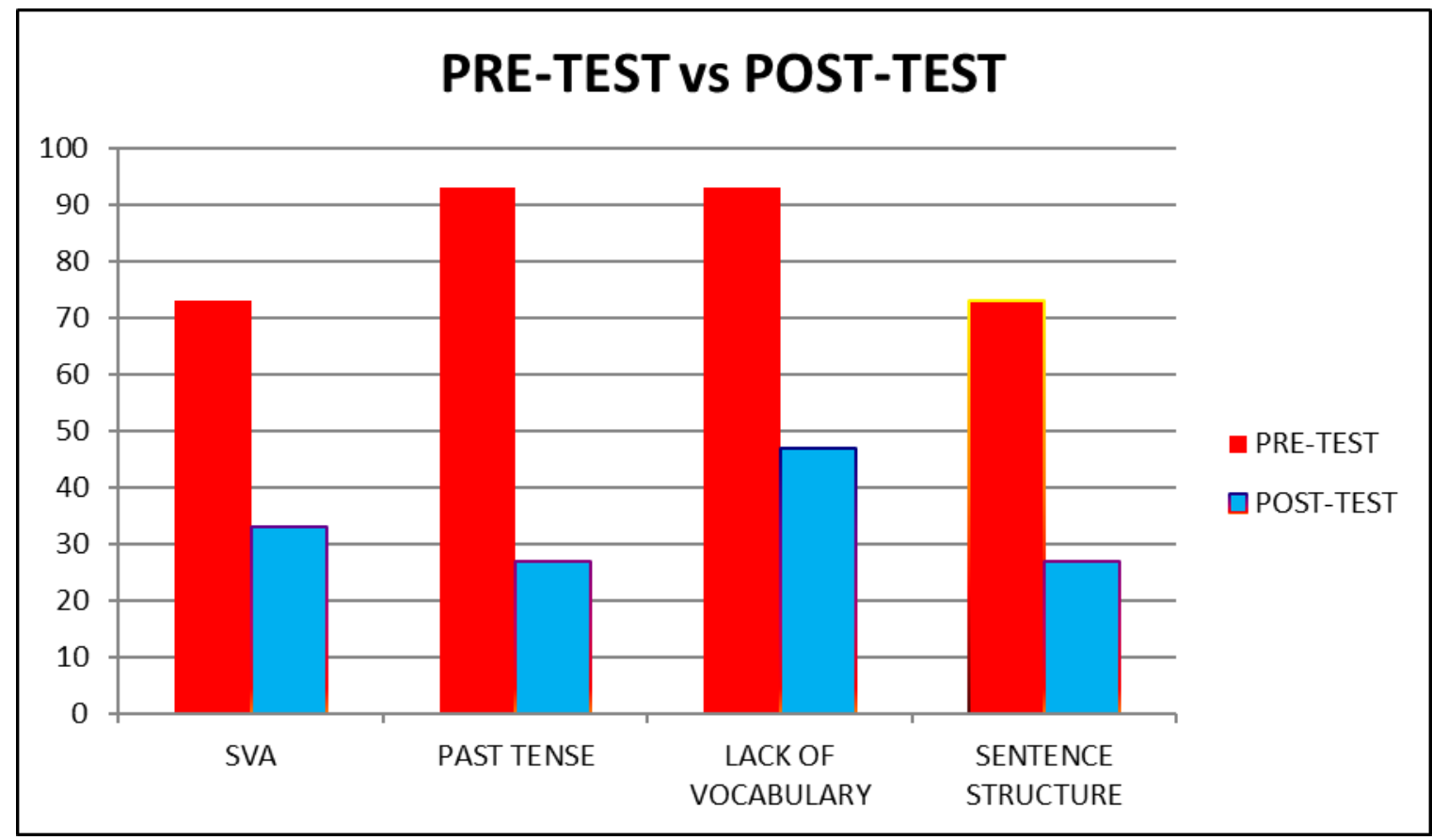

Graph 3: The Percentage Comparison Between Pre-test and Post-Test.

Based on the graph the errors in constructing sentences have decreased from $73 \%$ to $27 \%$. Meanwhile, the usage of not accurate and the vocabulary not in context in writing have are reduced from $93 \%$ in pre-test to $47 \%$ in post-test. There was a drastic reduce in the usage of improper past tense in a sentence. The percentage dropped from $93 \%$ in pre-test to $27 \%$ in the post-test. This grammatical error showed the most significant changes among the other three types of gaps in the intervention plan. The wrong usage of subject-verb-agreement has also shown some decrease from $73 \%$ to $33 \%$.

Apart from this, teacher also faced a number of challenges in completing this intervention. The noticeable challenge was the time constraint. Teacher could not conduct the intervention plan consequently for 6 weeks. It was because the student participants were involved in mid-term examination and co-academic activities which fall on the same week of the intervention plan. These events were unable to be avoided. On the other hand, teacher was also involved in some co-academic activities which distracted the continuity of the intervention plan.

\section{Conclusion}

This study has shed light on the manner of analyzing the students' written essay. It further shows that data-driven approach can help the teachers to identify the specific and common 
language problems that students have, so that they can focus and give more attention on these types of gaps. This kind of ideas of language learning problems is useful for the teachers because it provides on the common hot-spots in language learning. Thus, this intervention can be used in the preparation of effective teaching materials such as lesson plan and worksheets. Also, by identifying the common errors made by the students, the teachers can be well versed to assist the students to minimalize and overcome their language problems in writing. Therefore, all teachers are suggested to deeply give attention to their students' errors and practice innovative methods to face these complexities' in writing classes.

\section{References}

Corder, S. P. (1973). Introducing applied linguistics. Harmondsworth: Penguin Education.

Darus, S., \& Subramaniam, K. (2009). Error analysis of the written English essays of secondary school students in Malaysia: A case study. European journal of social sciences, 8(3), 483495.

Jamil, S. (2016). Analyzing common Errors in English Composition at Postgraduate Level in Khyber Pakhtunkhwa (Pakistan). Bulletin of Education and Research, 38(2), 53- 63.

Wood, J. F. (2017). Errors in second/foreign language learning and their interpretations. Education and Linguistics Research, 3(1), 1.

Zheng, C., \& Park, Tae-Ja. (2013). An analysis of errors in English writing made by Chinese and Korean university students. Theory and Practise in Language Studies, 3(2), 1342-1360. https://doi.org/10.4304/tpls.3.8.1342-1351

Zuo, W. (2017). "Teachers' Role in Dealing with Errors in Students' Second Language Learning" in Theory and Practice in Language Studies, Vol.7, No.8 [August], pp.644-650. Available online also at:

https://www.academypublication.com/ojs/index.php/tpls/article/viewFile/tpls070864 $4650 / 1199$ 